\title{
Introduction
}

West Iranian dialectology has been a well-established subdiscipline of Iranian linguistics for a long time, both in its historical and its modern, synchronic variants. Pioneering works, such as Geiger's Lautlehre (1891) or Tedesco's Dialektologie (1921), have rendered New West Iranian languages (Persian zabān) and dialects (gūyeš) one of the main objects of Iranian linguistics. Until this day, publications in English, German, French, and Russian, among others, make it a linguistically diverse international academic field, but, like in many other disciplines, English is gradually superseding the other idioms. Scholarly publications on New West Iranian languages and dialects in Persian appeared slowly only from the late 1920s onwards, when Iranian literati and scholars came into contact with Western scholarship on Iran and when a Western-style system of education and research began developing there. Two leading Iranian scholars during this pioneering period of Iranian dialectology were Moḥammad Moqaddam and Șādeq Kiyā, see the important studies of Moqaddam (1949) and Kiyā (1948).

\section{History of studies}

In Iran, Iranian dialectology developed in the context of the cultural-national ideology of the Pahlavi regime (1925-79). Iranian languages and dialects were seen as reservoirs of a "pure" Iranian culture with deep historical roots. Following Western scholars like Tedesco, they were given labels like "Median," emphasizing their historical depth and value. The study of Iranian idioms of Iranian Āżarbāyğān (the Āzarī dialects) was used ideologically to prove that its modern Turkophone population was of Iranian ethnic origin (e.g., by scholars like Moqaddam). Iranian dialectology gained further momentum in Iran, especially after 1960, and saw a gradual but continuous growth in scholarship. By the late 1970s, the output of publications in Persian had more or less reached the level of those in Western languages in quantity, although not yet quality.

The revolution of 1979, despite its Islamic ideological thrust, did not hamper the interest of Iranian scholars in Iranian dialectology. On the contrary, from the mid-1980s onwards, a steady increase in Persian publications on Iranian languages and dialects can be observed. In the decades that followed, the number of academic linguistic journals published in Iran increased from one (1985) to ca. fifteen (2021; see appendix 1). Among these, journals that specialize in Iranian dialectology have a noteworthy share (in 2021, ca. seven). The number of monographs published on the New Iranian languages and dialects likewise multiplied between 1985 and 2020. Besides an increase in numbers, the publications' scholarly quality has also risen steadily. While there continue to be published works of a purely descriptive nature, written partly by linguistic amateurs, a large number of high-quality analytical works can now be found, especially in academic linguistic journals. Following the general trend of linguistics in Iran, many of these works apply formal models of language analysis, which sometimes limits their empirical value. At the same time, empirically-based approaches, particularly typological but also historical, have seen a recent increase in Iran.

The increase in numbers of linguistic journals in Iran in recent years includes a problematic aspect. Following a law issued in the 2000s, which was fully implemented around ten years ago, two summaries of every Iranian PhD thesis and one of every MA thesis must be published in an academic journal. This has led to an increase in journal articles, and con- 
sequently of journals. These articles contain not only the main authors' name (i.e., the name of the thesis author), but also the names of their supervisor and other members of the committee, whose names usually precede that of the main author. In some journals, the articles' main author is acknowledged in a footnote. In other journals, however, the main author is mentioned only in the last position and is not given the recognition they deserve for writing the article.

\section{Challenges and opportunities}

Linguistic publications from Iran are less accessible to, and less perceived and used by, international linguists and Iranologists than they deserve to be. This is partly due to the language barrier. But even those specialists who do have access to Persian publications and are able to read them, often do not properly consider the available Persian publications in their (sub) fields. This is all the more regrettable since, for many years, all Iranian academic journals have become accessible on the Internet (through noormags.ir or the individual websites of most journals). Persian publications on Iranian linguistics and dialectology have also been regularly included in the annual volumes of the Bibliographie Linguistique (by this author, since ca. 1990).

Besides studies on Iranian languages and dialects, there are many publications in modern languages and dialects of Iran. In some areas/provinces, like Māzandarān, literature has been written in the local vernacular for many centuries (e.g., in Māzandarān, there is evidence of the Țabarī dialect since the $13^{\text {th }}$ century C. E.). In other areas, e.g., Lorestān, Tāleš, or Semnān, dialect poetry is an established genre and the number of local dialect poets is high, and although dialect literature was transmitted orally over a long period, it only started being written down in more recent times (in the $19^{\text {th }}$ or $20^{\text {th }}$ century). The publication in dialects traditionally includes poetry, proverbs, songs, riddles, etc. Prose works are seldom found, and their numbers have been slowly increasing only in recent years.

Literature written in Iranian dialects today still thrives largely below the radar of academic observance. Most dialect literature is produced locally by non-academic enthusiasts, for a limited local audience or readership. Even if the main genres (poetry, proverbs) are not suited as well as prose works would be for linguistic purposes, for many dialects they are the only published sources. They can (and should), therefore, be taken into account by linguists. In addition to what Iranian dialect literature offers to linguists, it could also provide opportunities for folklore studies, touching upon such issues as regional culture and identity.

\section{Definition of terms}

The Persian terms zabān and gūyeš are used differently than their English equivalents of "language" and "dialect." In the Iranian cultural worldview, Iran hosts - besides Persian - a great variety of idioms of Iranian origin, including Tālešì, Gīlakī, Semnānī, Lorī, etc., all of which are called güyeš (dialect). Only Kurdish and Balochi, spoken by large and compact culturally autonomous ethnic groups, would be perceived as "languages" (zabān) by most Iranians. International linguists, however, classify Tālešì, Gīlakī, Semnānī, and Lorī, as they do Kurdish and Balochi, i.e., not as varieties or dialects of Persian, but as separate West Iranian languages, whose grammars differ substantially from that of Persian. Dialects of Persian, in the international sense of the term, also exist and are called gūyeš, e.g., the dialects of the cities of Borūğerd or Q⿱亠乂⿰丿亅 
grammatical features from Persian but are much closer to Persian grammatically than are Tâleš̄i, Gīlakī, etc. For yet other linguistic variants that differ from Persian only slightly in pronunciation and in some lexemes, the term lahğe (accent) is preferred, e.g., some variants that are spoken in large cities, such as Eșfahān or Hamadān.

The main criterion distinguishing a "language" from a "dialect" in Iran is not the difference in grammatical structure, but the prestige. The term zabān (language) is associated with a measure of cultural autonomy and a history of literacy and (possibly also) official use, from which prestige has grown organically. Persian, as the official and national language, is the only idiom spoken in Iran that possesses these features in their entirety; Kurdish and Balochi follow at a great distance. The term zabān is therefore mainly reserved for Persian, and most other idioms (except Kurdish and Balochi) are usually called gūyeš, no matter how much they differ from Persian grammatically, or whether they are mutually intelligible with Persian or not. Unlike the English use of the term, most gūyeš spoken in Iran are not gūyeš (dialects) of Persian, but güyeš in their own right - a right that is below the level of Persian as a language. International scholarship appears to have been influenced by the Iranian use of these terms, by calling Iranian dialectology a discipline that deals with Iranian languages and dialects; it should more correctly be called "Iranian historical linguistics." Some Iranian linguists follow the international use of these terms, although divergent opinions still seem to exist (see Dabīr-Moqaddam 1387).

In all this, Iran is not an exception. As in many European countries, the exact use of terms like "language" and "dialect" is far from clear. Popular or general use of these terms may be at odds with scholarship. For example, the variants that are perceived as Schwitzerdütsch "dialects" of German (in Switzerland), even by many native speakers, could be considered dialects of a (non-standardized) language separate from German; and, for political reasons, Croatian is called a separate language from Serbian, although both varieties are actually almost identical grammatically.

The term gūyeš is not uniformly used in modern Iran. There is considerable variety, or even irregularity, in its use amongst different strata of society. It is not always clearly distinguishable from lahğe (accent). Güyeš is a modern academic linguistic term that was coined by the Iranian Language Academy (Farhangestān) in the early 20th century. It was derived from the older, unspecific (and rarely-used) term gūyeš (mode/act of speaking). Like many other Farhangestān terms, güyeš has established itself mostly in academia and among literate and urban Iranians. In the countryside, where most dialects are still spoken and where illiteracy continues to be widespread, there is a great variety of terms and expressions for the local village or city tongue. The autoglottonym (self-designation of the name of a language) is often simply derived from the village name, e.g., Ě̌t $\bar{a} r d \bar{\imath}$ (Eshtehārdī) for the Tâtī dialect of the city of Eštehārd (Tât is used for the larger ethnic community). There are historical glottonyms, like Rāğ $\bar{l}$, for the Central Iranian dialects spoken in parts of the Markazī and Eșfahān provinces today; this name is probably derived from the name of the city of Ragha or modern Rey (south of Tehrān).

Alternatively, people may name their native tongue using older terms, e.g., lafz (originally "word"), lafz-e deh ("village tongue"), dei (< dehī "from the village") or velàtì ("local [language]" < velāyatī, derived from velāyat "district," particularly in the vicinity of Eșfahān, e.g., in Mārbīn and Kūhpāye). They may not have separate terms at all, but simply call it "our language." In some areas, autoglottonyms exist that are derived from oft-heard expressions in the dialect, e.g., forms of the verb "to go." For example, speakers of Lārī 
(Fārs province) call their language ačomī (< ačom "I go"), speakers of (Central Iranian) Garakānī call their language burbasse (“come, go!” in Garakān̄̄, see Ğaẓve 1999), whereas others use similar terms, like buro-beše, just like speakers of northern Zazaki dialects (in East Anatolia) who call their language so-be ("go, come!"). Obviously, the existence of an autoglottonym common to all its speakers is not a prerequisite for the recognition of an idiom as a language. Uniform autoglottonyms are usually established by states or sophisticated administrations.

\section{Aims, scope, limits}

The present work aims to provide a comprehensive analytical bibliography mainly of publications on and in languages, dialects, and accents of Iran that have been published in Iran since the revolution of 1979 . While regional variants of Persian, which are usually called "accents" (lahğe) in Persian, are included, Persian itself, together with its (non-regional) sociolinguistic varieties, does not fall within the scope of this work. In the main analytical part of this work, the entries are arranged geographically and/or according to their genetic affiliation to a language or dialect group. This is followed by an alphabetical presentation of all the entries according to the author's names.

The definition of the time period is due to the fact that publications on New Iranian languages and dialects until the early and mid-1980s have been comprehensively bibliographed (including the most important works in Persian) in Schmitt (1989), and Navabi (1987). The limitation to works that were published in Iran is due partly to practical reasons: The inclusion of all English, German, French, Russian etc. publications since 1979 would have considerably delayed the publication of this work. More importantly, publications in Western languages are much more accessible to international scholars than Iranian publications. The latter have, until now, been underrepresented and partly neglected in international scholarship, despite their scholarly value. It seems reasonable, therefore, to present a work that concentrates on these and that highlights the hidden treasures and merits of Iranian (national) dialectology. Linguistic publications in Iran are mostly in Persian, but there are also a few publications in English and Kurdish, which will be included here. Some works published in Persian outside Iran will also be considered, not only from Afghanistan and Tajikestan (see below), but also Persian publications from Western countries. Like the Persian publications from Iran, they are less well-known and accessible to modern international Iranological scholarship. All publications from outside Iran and from Iran in languages other than Persian together make up less than two percent of the present work.

Publications from Afghanistan or Tajikestan (usually in Afghan or Tajik Persian) are included insofar as they deal with regional (sub-)variants of the Afghan or Tajik varieties of Persian or with other (Iranian) languages spoken in either of the two countries (chapter 3.). In numbers, the publication of books in both countries is much inferior to that of Iran, and the access to Afghan and Tajik publications and their coverage in this work was limited. The relatively low number of entries from Afghanistan and Tajikestan included in this work merely serves to give a casual impression of the academic dialectological output in both countries. A small number of publications from the Republic of Azerbaijan, in Azeri Turkic or Russian, on the Tāleš̄i and Tâtī languages is also included here, because these publications serve to complement Iranian publications on these languages and are (like Persian publications) not very accessible to international Iranological scholarship. In addition, 
a few translations of publications from Russian to Persian have been included, especially on languages/dialects that are understudied in Iran (e.g., Baškardī and Komzārī, see Moškalo 1383). Through their translation, they have, in a sense, become part of the Iranian dialectological state of the art and should not be missing from a work that aims to describe this state of the art. Translations from Western languages into Persian have not been covered because they are accessible in their original published form.

The scope of the present work includes linguistic publications on all Iranian languages, dialects and accents, and on all languages, dialects and accents (including non-Iranian) that are spoken in Iran, Afghanistan, or Tajikestan . This also includes Iranian languages spoken outside the three Iranophone countries, e.g., Zazaki (East Anatolia/Turkey), Ossetian (Caucasus/Russia), or Pashto (Afghanistan, northwestern Pakistan). The number of publications from Iran, Afghanistan, or Tajikestan on these languages is low, and publications from Turkey and Pakistan, where Zazaki and Pashto are spoken, are not considered. Publications on Kurdish from Iraq or Turkey, or on Balochi from Pakistan, are also not considered. It also includes all minority languages that are spoken in Iran, not only those that belong to the Iranian language family, but also to the Turkic and Semitic languages, and others, e.g., Armenian (chapter 4.). The number of these publications is lower than for the Iranian languages and dialects, although Azeri Turkish in particular (4.1.1.), the dominant minority language of Iran in terms of number of speakers, has seen a considerable increase in number of studies - both monographs and journal articles - over the last few decades.

While most publications covered here deal with New West Iranian idioms spoken in Iran today, chapter 2 concerns historical (pre-modern) forms of New Iranian idioms, e.g., the Fahlavīyāt poetry of the $11-17^{\text {th }}$ centuries CE. Chapter 5 is devoted to Iranian onomastics, i.e., to publications on names for places, persons, etc. in Iranian languages and dialects (except Persian) and in languages/dialects spoken in Iran. This chapter should be considered a "by-product" of the evaluation of linguistic publications; there are many more publications on names in Iran published in non-linguistic journals that were not covered in the present work. Two other subchapters deal with languages/dialects that are spoken by religious minorities (1.8.), and with regional secret codes spoken in Iran (1.9.). The titles that are entered in these thematic sections (1.8., 1.9., and 5.) are repeated in the geographic section to which they also belong, where they are marked with an asterisk $(*)$ (see Technical remarks at the end of this introduction).

To make up for the lack of publications in Western languages in this bibliography, a concise but representative selection of important recent works on New Iranian languages and dialects in Western languages since ca. 1985 is presented at the end of this introduction.

\section{Comprehensiveness}

The present work aims at comprehensiveness, even though it cannot fully achieve this. The ca. twenty academic linguistic journals that have been published in Iran since 1980 have been covered systematically and comprehensively up to the most recent 1,400 (summer 2021) issues of each journal (see the overview in appendix 1). Other academic journals that occasionally contain articles on dialectology were covered less systematically. Monographs on dialects from established academic publishers were covered more or less systematically. This includes collected works, such as conference volumes or Festschriften, that contain ar- 
ticles on dialectology and ethnographic or historical studies of cities, regions, or tribes that include at least one chapter about the language/dialect of the region under study.

Special attention has been given to non-academic and non-linguistic publications on and in local dialects. Many provincial capitals, but also smaller towns, boast local cultural centers, committed publishers, or enthusiastic individuals, who publish books on and in local dialects or on folklore or regional history that contain at least one chapter on the local dialect(s) (e.g., specimens of dialect poetry, proverbs, children's songs, remarks on grammar, etc.). The author has attempted to cover such publications as comprehensively as possible, including them even if they contain only a half-page sample on a local dialect (e.g., containing general information on its use), or sometimes even only one proverb in a local dialect. Many of these works are valuable and it should be up to future readers to decide whether the information that is contained in them is useful or not. Access to such publications is not easy to obtain. They are often produced and sold locally. Only a few reach the book market of the capital Tehran or are published there. To obtain these books it is necessary to travel to places like Rašt (Gīlakī), Haštpar (Tālešī), Xorramābād and Eșfahān (Lorī), Semnān (Semnānī), Šīrāz (Fārs dialects), Kermān (Kermān dialects), etc.

Non-academic publications on dialects, like amateur grammatical descriptions, are often valuable because the described linguistic facts, even if they may lack proper linguistic methods, speak for themselves. There are also non-academic publications of a more problematic nature, e.g., those that attempt to "prove" genetic relationships between certain languages or that try to etymologize dialect words without the proper methodology. Such works, whose number is low, may nonetheless contain interesting linguistic material, or they may be interesting from another (cultural, etc.) perspective; therefore, they have, on the whole, been covered in this work. For the reader to be made aware of their limitations, the label (non-academic) is given to them.

Around ten years ago, two new academic journals were established that focus on regional dialect literature and dialect folklore: Adabīyāt va zabānhā-ye mahallī-ye İrānzam$\overline{i n}(A Z M \bar{I})$ and Farhang va Adabìyāt-e Ámme (FAA). These are defining and developing an emergent academic field in Iran and are fully covered in the present bibliography. There are other local non-academic journals that specialize in folklore and local or regional history, e.g., Tāleš (Tâlešī) or Gīlevā (Gīlakī). These are usually published monthly or bimonthly and often contain short specimens of local dialect poetry, but, unlike the monographs or academic publications, the dialect texts are seldom translated, glossed, explained, or vocalized. They are therefore of limited use to linguists. Some of these journals have published well over a hundred issues. To include all dialectal articles from these journals would disproportionally inflate the bibliography. Therefore, only a selection of more important works or of exemplary issues from such journals has been included so that the reader is made aware of their existence as a resource. Readers interested in a more complete coverage may refer to the Index Iranicus, where some of these journals have been covered more comprehensively than in this work (e.g., in the Index Iranicus VI [ed. Afshar 2004] and the issues of the journal Gìlevā).

\section{Sources}

The basis of this bibliography is those books and periodicals that the author collected (in paper format) during his many travels to Iran between 1988 and 2019 (approximately 2,000 
titles). Further titles were retrieved from the library of the Near and Middle East department (Institut für den Nahen und Mittleren Osten) of the Ludwig Maximilian University of Munich (LMU), which hosts a remarkable collection of Iranian ethnographic and local historical works from the 1980s and 1990s. The remainder of the titles were retrieved in 2020 and 2021 from the following sources: various linguistic journals that were accessed online, Pejman Firoozbakhsh's contribution (see preface), various conference proceedings, and the bibliographical resources of the Index Iranicus. Through these additional resources, the number of entries grew from well over 2,000 (spring 2020) to ca. 3,600 (summer 2021).

The Index Iranicus series initiated by Iraj Afshar provides a comprehensive bibliography of articles published in Persian on all Iranological disciplines, including dialectology. Although it does not cover monographs, it is an important and extremely valuable reference work whose dialectological parts are rich and include publications that are not covered in this bibliography. After the publication of vol. VI (in 1383 [2004]), Iraj Afshar withdrew from the publication of the Index Iranicus and handed the work over to others. Since then, the bibliography has published another six volumes (VII-XII), concentrating on articles published in periodicals and neglecting collected works like conference volumes, etc. In 1395 [2016], 'Abbās Māfĩ published the first volume of a new series that covers collected works and aims to complement the periodical volumes.

Most publications for this work were seen and checked in the original (either in paper or electronic format) before they were entered in the present work. The translation and/or commentary that was added to each title (see below) was composed based on knowledge of the text wherever possible.

\section{Arrangement of the languages and dialects}

Finding a consistent, clear, and practical concept for the arrangement of the diverse idioms that are dealt with in this book has been a challenge. Obviously, non-Iranian (Turkic etc.) minority languages and dialects need to be grouped separately from Iranian ones, and Iranian languages from outside Iran (including local forms of Persian) could also be separated from those spoken in Iran. But, how should the great number and variety of Iranian languages, dialects, and accents that are spoken in Iran be arranged? Into how many chapters/sections and in which order should they be arranged? Most works that attempted to find an answer to this question, such as the Compendium Linguarum Iranicarum (ed. Schmitt 1989), have chosen a combination of genetic and areal/regional features. The present work follows this principle.

A purely areal/regional arrangement would hardly make sense: For example, the Lakī dialect spoken in Kelārdašt (Gīlān) should not be grouped with the neighboring Gīlakī dialects, and a Kurdish dialect spoken in Khorasan should not be grouped with Khorasan dialects; both should be classified in their genetic groups, namely Lakī and Kurdish. Both linguistic communities were displaced from their homelands and settled in their present place of residence centuries ago. The languages have subsequently become autochthonous in the regions where they are spoken today. The Laki and Kurdish varieties spoken there are no longer identical copies of the "homeland" varieties of Laki or Kurdish, but have become dialects of Lakī or Kurdish in their own right.

A purely genetic arrangement, on the other hand, could be used in theory, but would face practical problems. Whereas for many Iranian languages or dialect groups, e.g., Kurd- 
ish, Balochi, Gīlakī, Semnānī etc., the genetic affiliation and thus the "limits" of the language/dialect group(s), are more or less established, this is less true for other groups, e.g., the Central Plateau or the Baškardī dialects. The Central Plateau dialects are spoken over a large area spanning four provinces (Yazd, Eșfahān, Markaz̄, Qom) and may be subdivided arbitrarily into any number between around three and twenty genetic subgroups. Thus far, the Baškardī dialects have been poorly studied; they are spoken in parts of southern Kermān and Hormozgān and cannot always be clearly distinguished from other groups, such as the Bandarī dialects. Naturally, there are transitional zones between many neighboring dialect areas, e.g., between the Lorī and Fārs dialects that are spoken in Būšehr province. Even for some clearly-defined dialect groups, there may be transitional variants on the margins, e.g., southern Kurdish dialects that lean towards Lakī, or the Šahmīrzādī dialect (spoken in Semnān province) that lie genetically between the Semnānī and Māzandarānī dialect groups. The same is true of the Tātī and Tālešì dialect groups. They appear to be clearly distinct from each other, but transitional dialects may exist, and sound research work on this question has not yet been done.

Most dialects spoken in the provinces of Khorasan and Kermān are much closer grammatically and genetically to Persian than most güyešs from other provinces. They can be called "dialects" of Persian in the international sense of the word, but are still called güyeš in Iran. Their closeness to Persian may have made them "less interesting" to linguists than other, more independent, güyeš. This may have been the reason why linguistic work on them, especially on their genetic (sub)grouping, has, thus far, been relatively neglected.

Considering the many unresolved problems of subdivision and affiliation of languages and dialects in the provinces of Khorasan, Kermān, Hormozgān, Būšehr, etc., it was decided that, in these provinces, the approach should be regional rather than genetic. This does not exclude the genetic grouping of idioms spoken in these provinces that clearly belong to one of the "established" genetic groups (e.g., Khorasani Kurdish, see above). If the genetic affiliation of such a language cannot, however, be recognized from the publication, the dialect will be classified according to its location in its respective province (e.g., Khorasan, Kermān etc.), without laying claim to its genetic affiliation. Only the Baškardī dialect group spoken in parts of Hormozgān and southern Kermān is given a separate genetic subchapter among these provincial chapters, grouping all the publications where the name Baškard (or "Bašăgerd") occurs. It should be noted, however, that sound research on Baškardī is largely absent, and unrecognized publications on/in Baškardī are likely to be found in the regional chapters on dialects from Kermān and Hormozgān.

For some provinces, such as Hormozgān or Būšehr, the Atlas of the Languages of Iran (Anonby et al. 2015-2019) provides reliable information on dialect distribution and affiliation. The Atlas cannot help, however, where the geographical allocation of a linguistic variety is not specified, and in the case of mixed and transitional dialectal zones, insecurities remain. Despite the immensely valuable information that the Atlas provides, it cannot yet answer all the questions of linguistic affiliation on the level of historical-genetic analysis. It was therefore decided to allocate the linguistic varieties independently of the Atlas, based only on the information given in the publications.

Another established Iranian dialect group is Kumzārī, spoken in the Gulf region mostly beyond the borders of Iran, namely in the Sultanate of Oman (Musandam peninsula, ca. 3,000 speakers), but also in Iran (Lārak island, ca. 700 speakers). Since only one Persian publication on Kumzārī has been found (Afrāšsi 1391), besides the Persian translation of a 
Russian work on Baškardī (see Moškalo 1383), both entries have been left in the Hormozgān section.

The great variety and complexity of the central Iranian (Plateau) dialects has led to a mixed approach. Whereas the dialects of Yazd province are classified (regionally) as a separate group, the dialects of the province of Eșfahān have been subdivided into three groups - Great Kavīr (desert) dialects, dialects of the region of Kāšān, and dialects of Eșfahān province (without the region of Kāšān) - and the dialects spoken in the provinces of Markazī and Qom together constitute another separate group. These subgroupings are arbitrary, and various other subgroupings would be possible.

Supplementing the rules explained above, it was sometimes decided to introduce additional subdivisions of dialect groups or, when necessary or practical, to apply the rules more flexibly. For example, while the Gīlakī and Māzandarānī dialect groups are generally clearly defined, they actually form a dialect continuum, with the region around Tonekābon (as part of Māzandarān province) as a transitional zone. Some Iranian scholars consider the dialects of the Tonekābon area as part of Gīlakī, others as part of Māzandarānī, and still others as a separate group. For practical reasons, this work separates these dialects (the Tonekābon dialect group) from Gīlakī and Māzandarānī. This does not anticipate a decision on the affiliation of this group, which may only be made, if at all, after more research has been done. The separation of this group will hopefully facilitate such research. Other examples of the more flexible use of these rules include Sīvandī, which is a northwestern Iranian language isolate spoken in Fārs province and has therefore been separated, as a small group on its own, from the Fārs dialect group, and Behbahānī, which is grouped genetically as a Fārs dialect, although it is spoken in Khuzestan province (close to the province border with Fārs).

It should now be clear that there cannot be only one "obvious" or "correct" way of arranging the modern West Iranian languages and dialects. Alternative arrangements to those proposed here are possible and each choice will, to some extent, be arbitrary. Arrangements that select other features than regional and genetic affiliations, e.g., that are based on typological features (e.g., Lecoq 1989), are also possible, but have not been applied here because they are considered less suitable for a general overview. The choice made in the present work understands itself as a suggestion in an ongoing process. It was also an arbitrary but deliberate decision to begin the arrangement with northwestern Iran (Āzarī dialects), proceeding eastwards along the Caspian Sea, turning southwards through Khorasan, Sīstān/ Balochistan and the southern coast of Iran, and then continuing westwards before moving northwards with Lorī, Kurdish, etc., and finally arriving in Central Iran. The "direction" of this grouping is clockwise, and describes the (somewhat crooked) form of a snail.

\section{Five larger dialect groups: directions}

Based on the rules explained above, the Iranian languages/dialects spoken in Iran (excluding the accents of Persian) are subdivided into twenty-seven language/dialect units, each forming one section. For convenience, these twenty-seven sections are divided into five larger groups defined by their geographical direction (North, East, South, West, Central). Three of these groups (1.3. East, 1.4. South, 1.6. Central) are merely regional compounds arbitrarily joined by direction. The sections contained within them have little in common except that, often, the boundaries between two neighboring sections do not correspond to the linguistic boundaries. For example, in the southern group, Fārs dialects stretch into Būšehr province, 
Baškardī dialects cover parts of southern Kermān and Hormozgān, etc. Often (but not always), transitional dialects between two adjacent language or dialect areas exist or there is, at least, much linguistic exchange and mutual influence over the language boundaries.

For the other two groups (North and West), the situation is different. Both groups include languages and dialects that have more in common linguistically and culturally than each of the three other groups. For example, for many speakers of the Kurdish, Lakī, Gorani, and Lorī dialects in the western group, some kind of cultural framework exists that is rooted in a common history and shared cultural and nomadic traditions that, to this day, have repercussions, even if nomadism as a social form of life has, in the meantime, become part of their history. Not all the ethnic groups mentioned are included in this common cultural framework to the same degree. For example, speakers of southern Lorī dialects tend culturally more towards the Fārs and Qašqāy groups that are their neighbors to the south than to the Lak or Kurds. Nevertheless, this common cultural framework has brought about many mutual linguistic influences between these four languages.

For the northern dialect group (1.2.), the cultural framework common to the many dialects/ethnic groups involved is less marked, although most languages in this group have strong cultural and historical ties with at least one other language in the group, e.g., Tâti with Tālešì, Tālešì with Gīlakī, and Gīlakī with Tonekābonī and Māzandarānī. The ties of the Semnānī and Qașrānī group to other languages in this group appear to be less important. The cultural commonalities of the western and northern groups are reflected in the fact that, for both groups, a relatively large number of publications exist that deal with more than one language in the group, e.g., Tālešì and Gīlakī, Gīlakī and Māzandarānī, Lakī and Lorī, etc. This is not the case in any of the other three groups. For the northern and western groups, a separate section at the beginning of each group (1.2. North, 1.5. West) has therefore been added that includes all publications that deal with languages/dialects from at least two of the group's sections.

Another section (1.1.) is added at the beginning of the main bibliographical part on publications dealing with (West) Iranian languages or dialects in general, or with at least three languages/dialects from more than one dialect group or province. A publication on two languages/dialects is not included in the "General" section, but in the two sections to which both languages belong. One of the two publications will be marked by an asterisk (*) to indicate the "redundance" of the entry (see Technical remarks below).

\section{Structure and subdivision of the entries}

The twenty-seven sections on the Iranian languages/dialects, and the three additional sections on general West Iranian dialectology (1.1.), northern languages/dialects (1.2.1.), and western languages/dialects (1.5.1.) are quite diverse, also with respect to their length. Most of them contain between ca. forty and a hundred entries, but some contain much less (Sīvandī, 9; Qașrānī, 16; Tonekābonī, 22), and others considerably more (Lorī, ca. 350; Kurdish, more than 300; Gîlakī, more than 200). To help the reader quickly find what they are looking for, most sections are subdivided into more compact units. The degree of subdivision depends on the number of entries that each section contains. The basic subdivisions are "Grammar," "Lexicon," and "Literature." These are applied to all sections except the smallest (1.4.6. Sīvandī). Other smaller sections may lack one of the three subsections; e.g., the Qașrān section (1.2.8.) does not have a subsection for "Lexicon"; the "Grammar" section 1.2.8.2. is therefore im- 